\title{
Р. Ю. Почекаев
}

\section{ОБЩЕСТВЕННАЯ ЖИЗНЬ ТУРКМЕН АХАЛТЕКИНСКОГО ОАЗИСА В РОМАНЕ В. П. ЧЕРЕВАНСКОГО «ПОД БОЕВЫМ ОГНЕМ»*}

В статье анализируются сведения о реалиях туркменской жизни накануне и во время АхалТекинской экспедиции 1880-1881 гг., которые приводит в своем романе «Под боевым огнем» В. П. Череванский - крупный российский государственный деятель, ученый и известный писатель второй половины XIX - начала XX в., сам являвшийся участником этого похода. Помимо основной сюжетной линии, в произведении описываются особенности внутренних отношений между различными родоплеменными подразделениями и их предводителями, позиция туркмен в отношении соседей: Бухары, Хивы, Персии, - их отношения с Российской и Британской империями в процессе присоединения Средней Азии к России. Наряду с вымышленными (или выведенными под вымышленными именами) персонажами в романе действуют реальные исторические деятели: начальник Ахал-Текинской экспедиции генерал М. Д. Скобелев, полковник Н. Г. Петрусевич, военачальник текинцев Тыкма-сардар, ученый-востоковед А. Вамбери, британский журналист Э. О’Донован и др. Личное знакомство В. П. Череванского со своими героями позволило ему достоверно описать туркменские реалии в «экстремальный» период их жизни - накануне и во время присоединения Ахалтекинского оазиса к России, «оживив» сведения о них, известные по работам его современников и исследователей, и при этом не выказывая характерного для современных ему западных и некоторых российских литераторов ориенталистских воззрений.

Ключевые слова: Российская империя, Туркмения в ХІХ в., Ахал-Текинская экспедиция, государственность и право туркмен, «Большая игра», В. П. Череванский, колониальная литература

Владимир Павлович Череванский (18361914) сумел реализовать себя в разных сферах деятельности. В течение долгих лет он служил в органах Государственного контроля - руководителем Туркестанской (1868-1880) и Московской (1883-1884) торговых палат, товарищем государственного контролера (18891897). Завершил он свою карьеру в статусе члена Государственного совета и сенатора. Долгие годы пребывания в Средней Азии позволили ему хорошо узнать регион, в результате чего он приобрел во властных кругах репутацию одного из крупнейших знатоков ислама, став автором монографии «Мир ислама и его пробуждение» (1901) и ряда аналитических за-

Почекаев Роман Юлианович - к.ю.н., доцент, заведующий кафедрой теории и истории права и государства, Национальный исследовательский университет «Высшая школа экономики» (г. Санкт-Петербург) E-mail: rpochekaev@hse.ru

* Исследование выполнено за счет гранта РНФ, проект № 19-18-оо162 «Центральная Азия в международных отношениях XVIII-XIX вв.», реализуемого в Институте языков и культур им. Лъва Толстого (рук. Д. В. Васильев). Статья представляет собой расширенную версию доклада, представленного на ХLIII Лавровских чтениях (Санкт-Петербург, Музей антропологии и этнографии (Кунсткамера) РАН, 27-29 мая 2019 г.) писок, легших в основу нескольких законопроектов, касавшихся религиозной политики Российской империи в начале XX в. ${ }^{1}$

Не менее известен В. П. Череванский также как писатель и публицист. Уже в конце 1850-х гг. появляются его первые публицистические и художественные очерки в ряде российских периодических изданий: «Семейный круг», «Русский мир», «Петербургский вестник», «Сын Отечества». Однако свои наиболее значительные произведения он создал уже после того, как отошел от активной государственной деятельности. Эти произведения можно условно поделить на две категории. Первую составляют научные работы: вышеупомянутая монография, историческая хроника «Две волны» и своеобразное приложение к ней «Хронология событий в ходе борьбы России с татаро-монголами» (1898), - посвященные противостоянию России с евразийскими кочевниками. Ко второй категории можно отнести работы, которые сам автор именовал

\footnotetext{
${ }^{1}$ См., напр.: Особое Совещание по мусульманским делам 1914 года: Журналы. Казань, 2011. С. 36. Фундаментальные знания догматов ислама заставляют некоторых современных исследователей считать В. П. Череванского «известным и весьма образованным миссионером», см.: Россия и мусульманский мир: Инаковость как проблема. М., 2010. С. 145
} 
«историческими повествованиями», по сути же представлявшие собой научно-популярные книги, посвященные самому широкому кругу вопросов, о чем говорят даже их названия: «Исчезнувшее царство (эпоха Семирамиды)» (1906), «Последний вздох Византии» (1909), «Творчество русской силы» (1911), «Первая русская царица» (1913).

Особое место в творчестве В. П. Череванского, на наш взгляд, занимает произведение «Под боевым огнем», впервые опубликованное в 1896 г., переизданное в 1898 и 1906 гг., а затем в 2012 г. (на текст которого мы намерены опираться). Сам автор его определял также как «историческое повествование», однако по стилю и сюжету оно в большей мере представляет собой исторический роман, в котором есть и довольно запутанная любовная линия, и политическая интрига, и приключения в экзотических местностях Средней Азии. Однако от обычной исторической беллетристики это произведение отличают несколько особенностей.

Во-первых, несмотря на наличие любовной линии, ${ }^{2}$ произведение не может быть отнесено к романтической литературе, поскольку любовному сюжету посвящено сравнительно немного места. Основу сюжета составляет подготовка и реализация второй Ахал-Текинской экспедиции под командованием М. Д. Скобелева (1880-1881), в результате которой значительная часть так называемой вольной Туркмении вошла в состав России. Соответственно, много внимания уделено описанию политической ситуации в Туркмении и вокруг нее, подготовке похода, самим боевым действиям.

Во-вторых, в отличие от других «исторических повествований» В. П. Череванского, «Под боевым огнем» является в значительной степени автобиографическим произведением. Автор выведен под именем главного героя произведения - Бориса Сергеевича Можайского, который характеризуется Скобелевым как «контрольный тяжеловес», то есть высокопоставленный чиновник Государственного контроля, 3 в Ахал-Текинской экспедиции от-

\footnotetext{
${ }^{2}$ Современные издатели позволили себе изменить оригинальное название на «Любовь под боевым огнем», в результате чего поначалу может возникнуть впечатление, что речь идет о любовном романе, происходящем в «экзотических условиях» боевых действий в Средней Азии, хотя изначально автор, повидимому, ставил прямо противоположную цель - осветить военные события, «разбавив» их любовным сюжетом.

${ }_{3}$ См.: Череванский В. Любовь под боевым огнем. М., 2012. C. 33 .
}

вечает за снабжение, а после взятия крепости Геок-Тепе заботится о содержании попавших в плен туркменских женщин и детей. Все это в полной мере относилось и к самому В. П. Череванскому, занимавшему должность «полевого контролера» во время описываемых в романе событий (1880-1883). Как можно понять из текста произведения, автор во время экспедиции вел дневник, который и лег в основу его сочинения. Отсюда столь подробные описания подготовки экспедиции, закупок запасов продовольствия и транспортных средств (в первую очередь многих тысяч верблюдов), неоднократных столкновений и конфликтов с недобросовестными поставщиками и вороватыми интендантами. Все это позволяет рассматривать роман не только как художественное произведение, но и как своего рода источник сведений о второй Ахал-Текинской экспедиции. 4

В романе фигурирует некоторое количество вымышленных или же выведенных под вымышленными именами (как и сам главный герой) персонажей, но при этом присутствует и ряд исторических деятелей под собственными именами: генерал М. Д. Скобелев, полковник Н. Г. Петрусевич, полковник А. Н. Куропаткин, туркменский военачальник Тыкма-сардар и ряд других родоплеменных предводителей, австрийский ученый-востоковед А. Вамбери, скандально известный британский журналист Э. О’Донован и др. ${ }^{5}$ Со многими из своих героев (не только с русскими, но также западными и туркменскими) автор книги был лично знаком, что позволило ему создать весьма яркие их образы и вложить в их уста слова, вполне соответствовавшие позиции соответствующих деятелей. Таким образом, его произведение до некоторой степени представляет и «микроисторический» подход, позволяющий

\footnotetext{
4 В этом отношении, как представляется, «Под боевым огнем» по стилю, а также по хронологии и географии описываемых событий можно сопоставить с дилогией Н. А. Халфина о борьбе афганского народа против британской агрессии, см.: Халфин Н. А. Возмездие ожидает в Джагдалаке. Победные трубы Майванда (Историческое повествование). М., 1990.

5 В некоторых случаях загадочность автора в названии персонажей вызывает некоторое удивление. Так, например, начальник штаба экспедиции в романе фигурирует как полковник Гр-ков, хотя его статус и обращение к нему по имениотчеству (Николай Иванович) вполне однозначно указывают на то, что это Н. И. Гродеков (1843-1913), видный государственный деятель и востоковед. Аналогичным образом влиятельная туркменская аристократка, участница событий, в романе названа «Улькан-ханум», хотя в ней легко узнается ханша Гюль-Джамал, впоследствии сыгравшая решающую роль в присоединении к Российской империи Мервского оазиса в 1884 г., см., напр.: Тихомиров М. Н. Присоединение Мерва к России. М., 196о. С. 86, 147, 148, 160, 183, 218.
} 
обратить внимание на отношение конкретных исторических деятелей к описываемым событиям и влияние на их развитие. ${ }^{6}$

Несомненно, роман В. П. Череванского «Под боевым огнем» заслуживает подробного и многоаспектного анализа, однако в данной статье мы намерены более обстоятельно рассмотреть одну из его составляющих - сведения о туркменах Ахал-Текинского оазиса, против которых была направлена экспедиция М. Д. Скобелева, ставшая основной сюжетной линией произведения. Нас интересует, насколько корректно удалось автору передать свои впечатления по итогам общения с самими туркменами или же другими участниками экспедиции об организации внутреннего устройства этого народа и особенностях его взаимоотношений с соседними народами и государствами в «экстремальный» период противостояния российской экспедиции и последующего вхождения Ахал-Теке в состав Российской империи.

Ответ на подобный вопрос не вызывает существенных затруднений: изучение туркмен, включая вопросы их политического устройства и внешнеполитической деятельности, имело в России ко времени написания романа весьма длительную историю. Первые сведения о туркменах содержатся в записках российских авторов, побывавших в Персии, Хивинском ханстве и непосредственно в Туркмении задолго до Ахал-Текинской экспедиции. Этим вопросам уделили внимание, в частности, ученый К. И. Габлиц (участник экспедиции капитана М. И. Войновича в Иран в 1781-1782 гг.), полковник Н. Н. Муравьев, совершивший две экспедиции в Туркмению в 1819-1821 гг., ученый и дипломат Г. С. Карелин, побывавший в Туркмении в 1832 и 1836 гг., Г. И. Данилевский, глава посольства в Хиву в 1842 г., офицер И. Ф. Бларамберг, несколько раз побывавший в Туркмении в 1830-1840-е гг., и др. Присутствует описание туркменских реалий и в записках ряда участников Ахал-Текинской экспедиции, в том числе героев книги «Под боевым огнем» - впоследствии видных военачальников, государственных деятелей и «военных востоковедов» Н. И. Гродекова и А. Н. Куропаткина.

Прежде всего, вызывает интерес описание В. П. Череванским социально-политической организации туркмен. Вслед за другими авто-

\footnotetext{
${ }^{6}$ См. подробнее: Побережников И. В. Микроистория: действия и структуры в историческом контексте // Урал. ист. вестн. 2010. № 4 (29). С. 8-13.
}

рами он подчеркивает такую их особую черту, как вольнолюбие, нашедшую отражение в непризнании какой бы то ни было власти и в свободе выражения собственной позиции. ${ }^{7}$ Даже простые туркмены считались полноправными членами общества, и ни низкое происхождение, ни бедность не являлись препятствием для участия в принятии политических решений на общем совете - генгеше (маслахате), особенно в преддверии надвигавшейся угрозы, которой должны были противостоять все способные держать оружие. В. П. Череванский весьма ярко описывает сцену общения британского агента Уильяма Холидея с туркменами, во время которой чопорного англичанина периодически прерывают именно представители бедноты. На требование англичанина «убрать этих крикунов» его же собственный переводчик отвечает: «Здесь никого нельзя трогать. Они хозяева здешней земли». ${ }^{8}$

Бедность или богатство отнюдь не являлись условием или препятствием для карьерного роста, равно как и наличие ханского звания, которое мог присвоить себе любой состоятельный или уважаемый туркмен. ${ }^{9}$ Так, например, богатый Софи-хан, даже несмотря на усилия своей влиятельной супруги Улькан-ханум, не сумел попасть в так называемое «четверовластие» - своеобразный постоянно действующий исполнительный орган текинцев. И напротив, бедность простого туркмена Мумына, отличавшегося храбростью в набегах, не помешала ему стать есаулом. ${ }^{10}$

Нашло отражение в произведении В. П. Череванского и независимое положение туркменских женщин, существенно отличавшееся от образа «угнетенной женщины Востока», с которым русским и европейцам приходилось сталкиваться в среднеазиатских ханствах, Иране, Индии и т. д. ${ }^{11}$ В романе «Под боевым огнем» женщины-туркменки описаны как активные участницы событий, нередко оказывавшие влияние на их дальнейшее разви-

\footnotetext{
7 См.: Бларамберг И. Ф. Воспоминания. М., 1978. С. 64.

8 Череванский В. Указ. соч. С. 202.

9 См., напр.: Галкин М. Н. Этнографические и исторические материалы по Средней Азии и Оренбургскому краю. СПб., 1868. С. 71; Куропаткин А. Туркмения и туркмены. СПб., 1879. C. 32; Он же. Завоевание Туркмении (Поход в Ахал-теке в 1880-1881 гг.). С очерком военных действий в Средней Азии с 1839 по 1876 гг. СПб., 1899. С. 96, 101.

${ }_{10}$ См.: Череванский В. Указ. соч. С. $71,84$.

${ }^{11}$ См., напр.: Записка И. В. Виткевича // Записки о Бухарском ханстве. М., 1983. С. 88; Куропаткин А. Н. Завоевание Туркмении. С. 94.
} 
тие. ${ }^{12}$ Так, когда вышеупомянутый англичанин Холидей упрекает туркмен, что «женщины кричат здесь громче мужчин», Улькан-ханум ехидно отвечает ему: «У твоей королевы нет бороды точно так же, как у меня». Не колеблются туркменки в отстаивании своих прав и перед собственными соотечественниками. Когда военный вождь Тыкма-сардар, стараясь утихомирить чрезмерно активных участниц обсуждения, заявляет: «Вы забыли, что десять женщин составляют одну курицу», - старухи тут же отвечают ему: «Это, сардар, не у нас, это у бухарцев... Ты долго жил вдали от нас и забыл, что текинская женщина плетет нагайку только для лошадиного зада, а не для своей спины». ${ }^{13}$

Большой интерес представляет описание у В. П. Череванского системы власти и управления ахал-текинских туркмен. Несмотря на отмеченное выше вольнолюбие этого народа, они имели определенные институты власти, решения которых готовы были признавать при определенных обстоятельствах - в частности, как раз при подготовке к отражению грозящей опасности. Высшим органом власти являлось вышеупомянутое «четверовластие», включавшее в себя представителей от четырех самых влиятельных «колен»-родов племени Теке. Этот орган власти занимался хозяйственными вопросами, обеспечивал запасы для населения, разбирал споры; в него входили самые уважаемые родоплеменные предводители. ${ }^{14}$

Значительная власть сосредотачивалась в руках выборного военного вождя - сардара. Таковым в романе представлен реальный исторический деятель Тыкма-бай, возвышение которого происходило в прямом соответствии с ценностными представлениями туркмен: с 12 лет он участвовал в набегах-«аламанах» на Персию, в 15 попал в плен, был выкуплен за тысячу туманов, которые уже вскоре сумел вернуть за счет новой добычи, неоднократно одерживал победы над врагами и т. д. ${ }^{15}$ Хотя за свои заслуги Тыкма именовался сардаром «до конца его дней», фактически власть военного вождя имела место лишь в условиях военных

\footnotetext{
12 Впрочем, под пером В. П. Череванского туркменки нередко предстают как склочные и сварливые старухи, скорее вносящие беспорядок в обсуждение, чем способствующие принятию того или иного решения.

${ }_{13}$ Череванский В. Указ. соч. С. 68, 202.

${ }^{14}$ См.: Там же. С. 71. См. также: Аминов И. И. Организационно-правовые основы становления и развития российскотуркменских отношений (1714-1917 гг.). М., 2017. С. 149.

${ }_{15}$ См.: Череванский В. Указ. соч. С. 62.
}

действий или очередного аламана. Более того, совершенно необязательно именно ему следовало возглавлять подобные набеги: Череванский отмечает, что «в его недолгое отсутствие теке поаломанили без его согласия пограничное сельбище курдов». ${ }^{16}$ Автор романа отмечает достаточно четкое разграничение полномочий «четверовластия» и сардара, который в книге говорит, что повинуется «власти текинского народа» «в спокойное время». Но «когда... стране и... стадам угрожает опасность, сардар становится выше власти народа» и даже председательствует в «четверовластии». Последнее, впрочем, своим авторитетом само предоставляет ему всю полноту власти: «четверовластие еще раз подтвердило права сардара - права на жизнь и смерть», а также право распоряжаться всеми припасами, которые ранее собирали члены «четверовластия». ${ }^{17}$ Это в полной мере соотносится со сведениями других российских очевидцев, отмечающих, что во время боевых действий или походов туркмены беспрекословно повинуются начальнику отряда, решающему любые споры и разногласия. ${ }^{18}$

Особенности социально-политического устройства туркмен-текинцев, их вольнолюбие и самостоятельность, а также образ жизни привели к тому, что они практически всегда находились в напряженных отношениях со своими соседями - другими народами и государствами Центральной Азии. ${ }^{19}$ Высокомерное отношение туркмен к оседлым соседям весьма красноречиво представлено в романе Череванского, герои которого даже в условиях опасности в ответ на предложение англичанина О’Донована «поднять всех мусульман» против русских, презрительно отвергают помощь всех своих соседей. Больше всего негативных оценок вызывают персы в силу своего вероисповедания: «Собак-персиян мы не возьмем в товарищи, даже если бы русские отняли у нас воду... Сунниты не могут звать на помощь шиитов»; «Если Аллах прогневается на свой народ, то пусть он наложит на него руку неверного, а не шиита». ${ }^{20}$ Хивинцы не могут оказать

\footnotetext{
${ }_{16}$ Там же. С. $65,66$.

${ }_{17}$ Там же. С. 67, 78, 205.

18 См., напр.: Петриченко К. Рассказы каспийского моряка // Русский вестник. 1857. № 6. С. 598, 599.

19 См.: Куропаткин А. Туркмения и туркмены. С. 32, 33; Путешествия Г. С. Карелина по Каспийскому морю // Записки Императорского Русского географического общества по общей географии. 1883. Т. 10. С. 94, 205, 208.

20 Череванский В. Указ. соч. С. 82, 205.
} 
поддержки, поскольку до сих пор не оправились после похода К. П. фон Кауфмана на Хиву 1873 г.: они «теперь на положении собак, побитых сердитым хозяином». Не вызывают восторга у туркмен и боевые качества бухарцев: «Да разве бухарцы могут воевать как следует? Они по преимуществу купцы. Взгляните на их халаты и чалмы из парчи и кашемира и судите сами, какие они воины». ${ }^{21}$ Афганцы представляются туркменам недостаточно надежными: «Для них найдутся у русских генералов серебряные пули. Когда они ловят те пули, то сейчас же забывают о братьях-мусульманах». ${ }^{22}$ Из всех соседей только такие же туркмены-текинцы из Мерва представляются им достойными партнерами в войне с русскими, и их помощь они сердечно принимают. ${ }^{23}$

Несмотря на столь враждебное отношение, соседние государства и другие политические игроки на среднеазиатской международной арене не могли не считаться с многочисленными и воинственными туркменами-текинцами. Неудивительно, что могущественные мировые империи старались так или иначе решить «туркменский вопрос», обеспечив себе лояльность кочевников в условиях соперничества в регионе - так называемой «Большой игры». Естественно, когда Россия сделала ставку на открытое военное давление на туркмен и прямо обозначила себя как их противник, ее главный соперник Англия постаралась использовать ситуацию в своих интересах. ${ }^{24}$ Интересы Англии продвигают такие герои романа, как австро-венгерский востоковед А. Вамбери (русофобия которого в произведении В. П. Череванского нисколько не преувеличена) и два английских агента у туркмен - Э. О’Донован и У. Холидей (из которых второй является вымышленным героем, несомненно, имевшим реальный прототип).

А. Вамбери появляется в романе эпизодически, в качестве автора двух лекций «о положении России в стране воинственных туркмен», которые он читает в одном из лондонских салонов. На наш взгляд, автору романа прекрасно

\footnotetext{
${ }^{21}$ Там же. С. 88.

22 Там же. С. 88, 89.

23 См.: Там же. С. 90, 91, 93.

${ }^{24}$ См. подробнее: Васильев С. Д. Британское влияние на политику шахского правительства в отношении туркменских племен. Превращение Ирана в театр политического противостояния России и Великобритании // Центральная Азия на перекрестке европейских и азиатских политических интересов: XVIII-XIX вв.: сб. науч. тр. междунар. семинара. М., 2019. C. 291-293, 297, 298.
}

удалось показать в контексте международного положения туркмен и неприязнь востоковеда к России, и его англоманию, и претензии (не всегда обоснованные) на знание прошлого и настоящего Центральной Азии. При этом его лекции носят отнюдь не научный, а чисто политический и даже агитационный характер. Он сразу же начинает пугать англичан «казачьим натиском» на Азию, в результате которого не будет «больше таджиков, узбеков, каракалпаков, каракиргизов! Все это не более как мещане русского царства». Помощь туркменам он называет «священной обязанностью» Англии, от которой требует для отважных туркмен ружья, порох и инструкторов. При этом он успешно использует весьма распространенную в то время в Европе «страшилку»: «Русские войска в Азии... ожидают только приказа, чтобы двинуться в Индию», - и пророчествует, что в случае «равнодушия» Англии «перед этим перемещением центров исторической тяжести» (имеется в виду грядущий захват Ахал-Текинского оазиса Россией) «сибирская казачка может придти к вам в Индию доить священную корову на площади Мадраса». ${ }^{25}$

Журналист О'Донован действует уже непосредственно в Ахал-Теке, ${ }^{26}$ выдавая себя за полковника (затем - даже «джанарала»), полномочного представителя Британской империи. Он заявляет, что «отныне королева инглези и сардар теке все одно что брат и сестра». ${ }^{27} \mathrm{OH}$ выразительно расписывает, какие негативные последствия ждут туркмен, если русские покорят их: «По русским законам нельзя ставить кибитки, кто где хочет, и что в России каждый должен умереть там, где он родился... Каждому из вас дадут по кусочку земли, а остальное отберут для сербазов»; «А кого поймают на аломане... заставляют пешком идти в Сибирь». ${ }^{28}$

\footnotetext{
${ }_{25}$ Череванский В. Указ. соч. С. 51-55.

26 В дальнейшем О'Донован прожил некоторое время в Мерве, где вел себя примерно так же, как и среди ахал-текинских туркмен, однако местные жители достаточно быстро раскусили его и, продержав некоторое время на положении пленника, выпроводили из города, в результате чего он стал на долгое время посмешищем в глазах международной общественности, см.: Лессар О’Донован - хан мервский // Туркестанский сборник. 1883. Т. 359. Сам журналист, однако, не растерялся и выпустил объемную книгу, посвященную его пребыванию в Мерве, в которой он, конечно же, превозносит свои действия и их результаты, см.: O’Donovan E. The Merv Oasis. Travels and adventures east of the Caspian during the years 1879-80-81. New York, 1882-1883. Vol. 1-2.

27 Череванский В. Указ. соч. С. 63, 75.

${ }_{28}$ Там же. С. 76-77. Весьма любопытной в данном случае предстает искаженная и утрированная англичанином характеристика российских методов фронтирной модернизации входящих в состав России национальных регионов с целью
} 
В качестве помощи он сулит ахалтекинцам золотые горы, обещая множество ружей, пушек, патронов и т. д., однако всячески избегает каких-либо конкретных обещаний, и когда предводители туркмен буквально припирают его к стенке требуя определенности, он просто-напросто сбегает в Иран.

Риторика другого англичанина - У. Холидея, прибывшего в Ахал-Теке уже непосредственно перед его осадой и взятием русскими войсками, существенно отличается от слов его предшественника. Он откровенно игнорирует вопросы туркмен относительно оружия и боеприпасов, которые так щедро обещал О’Донован, и ограничивается призывами «напрячь все усилия, чтобы разбить вашего врага. Не допускайте его опереться на вашу землю, иначе вы лишитесь драгоценной для вас свободы». ${ }^{29}$ Его поведение отрезвляет даже самых горячих сторонников союза с Англией. И теперь вожди текинцев на слова сардара «Рассчитывать ли текинскому народу в войне с русскими на помощь инглези?» отвечают: «Нет, текинскому народу не следует рассчитывать на помощь инглези. До сих пор мы слушали от послов королевы одни сердечные слова, а где ее пушки и порох?»; «Инглези, как и афганцы, ведут дружбу только со своим карманом».30

В отличие от «дружественных» англичан, представители России, несмотря на открытую враждебность к туркменам, не могут не признать их отваги и воинских талантов. Например, М. Д. Скобелев отмечает, что эти «полудикари» сумели выстроить Геок-Тепе «крепость внушительного значения». ${ }^{31}$ И даже во время боевых действий русские солдаты восхищаются тем, что «текинцы дрались молодцами», «теке не сдаются в плен», «чекинец бьет в глазок на выбор» и т. д. ${ }^{32}$ Автор как бы подводит читателя к мысли, что это восхищение противником (в отличие от высокомерия британцев по отношению к среднеазиатским

их освоения и постепенного распространения на них российских методов управления и правового регулирования, см. подробнее: Побережников И. В. Фронтирная модернизация как российский цивилизационный феномен // Россия реформирующаяся. М., 2013. Вып. 12. С. 261; Он же. Модернизации в истории России: направления и проблемы изучения // Урал. ист. вестн. 2017. № 4 (57). С. 42.

29 Череванский В. Указ. соч. С. 202. При анализе подобных сюжетов нельзя не провести параллели с сегодняшней риторикой западных политиков по поводу «российской агрессии».

${ }_{30}$ Там же. С. 205.

${ }^{31}$ Там же. С. 32.

${ }^{22}$ Там же. С. 294, 310. Ср.: Аминов И. И. Указ. соч. С. 154, 155. народам) в дальнейшем стало основой для выстраивания дружественных отношений между российскими властями и туркменами, признавшими подданство Российской империи, с учетом особенностей их правового положения в составе Закаспийской области и сохранением традиционных институтов власти и управления. ${ }^{3}$

Несомненно, роман «Под боевым огнем» можно отнести к образцам так называемой колониальной литературы, которая как раз в это время (1880-1900-е гг.) начинает складываться в России именно по итогам присоединения к империи Средней Азии. Описание туркменских реалий, данное В. П. Череванским, отчасти позволяет провести сравнение с аналогичными описаниями жизни и быта среднеазиатского населения, присутствующими в произведениях Н. Н. Каразина, являвшегося, пожалуй, наиболее ярким представителем этого жанра в России. ${ }^{34}$ Однако, в отличие от Каразина, старавшегося в своих произведениях не только показать экзотику Средней Азии и ее жителей, но и подчеркнуть облагораживающее, цивилизующее влияние имперской власти на регион (как и некоторые другие российские литераторы и государственные деятели рубежа XIX-XX вв.),35 Череванский ограничивается лишь констатацией вышеприведенных особенностей внутреннего и внешнего положения туркмен. Это вполне объяснимо: роман «Под боевым огнем» посвящен военным событиям и положению туркмен в условиях военных действий, а не последующему укреплению российской власти в регионе, то есть «завоеванию», а не «устроению». ${ }^{6}$

\footnotetext{
33 См. подробнее: Караш Хан Оглы (Йомуд-хан). Местный суд в Закаспийской области (Народный суд). Историко-критический очерк. Ташкент, 1922. С. 7, 8; Васильев Д. В. Цели и задачи Российской империи в Закаспийском крае при создании новой системы управления // Центральная Азия на перекрестке европейских и азиатских политических интересов: XVIII-XIX вв.: сб. науч. тр. междунар. семинара. М., 2019. C. 285, 289; Тухтаметов Ф. Т. Правовое положение Туркестана в Российской империи: Вторая половина XIX века. Уфа, 1999. С. 39 , 40. Ср.: Побережников И. В. Фронтирная модернизация на востоке Российской империи: региональные вариации // Урал. ист. вестн. 2018. № 4 (61). С. 74.

${ }^{34}$ См.: Шафранская Э. Ф. Туркестанский текст в русской культуре: Колониальная проза Николая Каразина (историколитературный и культурно-этнографический комментарий). СПб., 2016.

35 См., в частности: Васильев Д. В. Классический пример ориентализма. Мемуары К. К. Палена как взгляд высокопоставленного чиновника на миссию России в Туркестанском крае // Вестн. Оренбур. гос. пед. ун-та. 2018. № 4 (28). С. 87-100.

${ }^{36}$ Преимущества российского имперского правления для населения Средней Азии нашли отражение в других произведениях Череванского - в таких, как «Две волны» и «Мир ислама», носивших, как уже отмечалось, более научный (и отчасти политический) характер.
} 
Итак, соответствуют ли сведения в романе В. П. Череванского о туркменах информации других авторов, писавших на основе личного знакомства с этим народом? Полагаем, что вышеприведенный анализ позволяет дать утвердительный ответ. Конечно же, мы не можем использовать сведения, содержащиеся в романе, как самостоятельный исторический источник об особенностях внутреннего и внешнего положения туркмен накануне и в период их вхождения в состав Российской империи. Тем не менее в сочетании с другими известными нам источниками, как представляется, информация, содержащаяся в романе «Под боевым огнем», может представлять определенную ценность, поскольку позволяет до некоторой степени оживить сведения официальных документов и научных трудов по данной тематике.

\section{Roman Yu. Pochekaev}

Candidate of Juridical Sciences, National Research University "Higher School of Economics" (Russia, Saint Petersburg)

E-mail: rpochekaev@hse.ru

\section{THE LIFESTYLE OF THE AKHAL-TEKE OASIS TURKMENS IN THE NOVEL OF V. P. CHEREVANSKY "UNDER THE BATTLE FIRE”}

The article analyzes data on the realities of Turkmen life before and during the Akhal-Teke expedition of $1880-1881$ contained in the novel "Under the battle fire" by V. P. Cherevansky, a highranking statesman, scientist and famous writer of the second half of $19^{\text {th }}-$ early $20^{\text {th }}$ century, who himself was a participant of this expedition. In addition to the main plotline, the novel describes specific features of relations between various Turkmen tribes and their leaders, position of Turkmens towards neighbor states such as The Emirate of Bukhara, The Khanate of Khiva, Persia, their relations with the Russian and British Empires during the process of joining the Central Asia to Russia. Together with invented characters (or figured under false names) real historical figures are acted in the novel: general M. D. Skobelev, colonel Petrusevich, Turkmen leader Tykma-sardar, orientalist A. Vambery, English journalist E. O'Donnovan and others. V. P. Cherevansky's personal acquaintance with his characters allowed him to faithfully describe Turkmen realities during the "extreme" period of their life (before and during the joining of the Akhal-Teke oasis to the Russian Empire) and enliven information of his contemporaries and scholars avoiding "oriental" views typical for contemporary western and some Russian literati.

Keywords: Russian Empire, $19^{\text {th }}$ century Turkmenistan, Akhal-Teke expedition, Turkmen state system and law, "Great Game", V. P. Cherevansky, colonial literature

\section{REFERENCES}

Aminov I. I. Organizatsionno-pravovye osnovy stanovleniya i razvitiya rossiysko-turkmenskikh otnosheniy (1714-1917 gg.) [Organizational and legal foundations of establishment and development of RussianTurkmen relations (1714-1917)]. Moscow: Yurlitinform Publ., 2017. (in Russ.).

Karash Khan Oglu (Yomud Khan). Mestnyy sud v Zakaspiyskoy oblasti (Narodnyy sud). Istoriko-kriticheskiy ocherk [Local court in the Transcaspian region (People's Court). Historical and critical essay]. Tashkent: Tipografiya O.G.P.U. Turkrespubliki Publ., 1922. (in Russ.).

Poberezhnikov I. V. [Frontier modernization as Russia's civilization phenomenon]. Rossiya reformiruyushchayasya [Reforming Russia]. Moscow: Novyy khronograf Publ., 2013, iss. 12, pp. 246-274. (in Russ.).

Poberezhnikov I. V. [Frontier modernization in the east of the Russian Empire: regional variations]. Ural'skij istoriceskij vestnik [Ural Historical Journal], 2018, no. 4 (61), pp. 72-80. DOI: 10.30759/1728-9718-20184(61)-72-80 (in Russ.).

Poberezhnikov I. V. [Micro-history: actions and structures in historical context]. Ural'skij istoriceskij vestnik [Ural Historical Journal], 2010, no. 4 (29), pp. 8-13. (in Russ.).

Poberezhnikov I. V. [Modernizations in the history of Russia: trends and investigation problems]. Ural'skij istoriceskij vestnik [Ural Historical Journal], 2017, no. 4 (57), pp. 36-45. (in Russ.).

Rossiya i musul'manskiy mir: Inakovost' kak problema [Russia and the Muslim World: Otherness as a Problem]. Moscow: Yazyki slavyanskikh kul'tur Publ., 2010. (in Russ.). 
Shafranskaya E. F. Turkestanskiy tekst $v$ russkoy kul'ture: Kolonial'naya proza Nikolaya Karazina (istoriko-literaturnyy i kul'turno-etnograficheskiy kommentariy) [Turkestan text in Russian culture: colonial prose of Nikolay Karazin (historical-literary and cultural-ethnographic commentary]. Saint Petersburg: Svoe izdatel'stvo Publ., 2016. (in Russ.).

Tikhomirov M. N. Prisoedinenie Merva $k$ Rossii [Accession of Merv to Russia]. Moscow: Izdatel'stvo vostochnoy literatury Publ., 1960. (in Russ.).

Tukhtametov F. T. Pravovoe polozhenie Turkestana $v$ Rossiyskoy imperii: Vtoraya polovina XIX veka [Legal statement of Turkestan in the Russian Empire: second half of $19^{\text {th }}$ century]. Ufa: BashGU Publ., 1999. (in Russ.).

Vasil'ev D. V. [A classic example of orientalism. Memoirs of K. K. Palen as a view of a high-ranking official on the mission of Russia in the Turkestan region]. Vestnik Orenburgskogo gosudarstvennogo pedagogicheskogo universiteta [Vestnik of Orenburg State Pedagogical University], 2018, no. 4 (28), pp. 87-100. DOI: 10.32516/2303-9922.2018.28.8 (in Russ.).

Vasil'ev D. V. [Goals and objectives of the Russian Empire in the Trans-Caspian region while creating a new administrative system]. Tsentral'naya Aziya na perekrestke evropeyskikh i aziatskikh politicheskikh interesov: XVIII-XIX vv.: Sbornik nauch. trudov mezhdunarod. seminara [Central Asia at the crossroad of European and Asian political interests: $18^{\text {th }}-19^{\text {th }}$ centuries: Collection of sci. papers of the international seminar]. Moscow: OntoPrint Publ., 2019, pp. 282-290. (in Russ.).

Vasil'ev S. D. [British influence on the policy of Shah's government towards Turkmen tribes. Tranformation of Iran into the seat of political confrontation of Russia and Great Britain]. Tsentral'naya Aziya na perekrestke evropeyskikh i aziatskikh politicheskikh interesov: XVIII-XIX vv.: Sbornik nauch. trudov mezhdunarod. seminara [Central Asia at the crossroad of European and Asian political interests: $18^{\text {th }}-19^{\text {th }}$ centuries: Collection of sci. papers of the international seminar]. Moscow: OntoPrint Publ., 2019, pp. 290300. (in Russ.). 